\title{
Noise pollution at Ghanaian Social Gatherings: the case of the Kumasi Metropolis
}

\author{
${ }^{1}$ Abankwa E.O., ${ }^{2}$ Agyei-Agyemang A., ${ }^{3}$ Tawiah P.O. \\ ${ }^{1}$ Department of Mechanical and Industrial Engineering, University for Development Studies, Tamale, Ghana \\ ${ }^{2,3}$ Department of Mechanical Engineering, KNUST, Kumasi, Ghana \\ Corresponding Author: Abankwa E.O
}

\begin{abstract}
Kumasi the capital of the Ashanti Region in Ghana has been observed to have high noise pollution. It has been observed that social gatherings, especially church services and funeral gatherings, are the main contributors to such noise. Measurements of noise levels were carried out in three churches and three funeral gatherings, using DT-8852 Precision Digital Sound Level meter, to investigate whether they conform to the Environmental Protection Agency (EPA) standards, and if not, to find out how much they exceed the EPA prescribed limits. Noise levels from the Church A, Church B and the Church C were $78.3 \mathrm{dBA}, 82.8 \mathrm{dBA}$ and $81.4 \mathrm{dBA}$ respectively. Funeral ground 1 recorded the highest noise level of $84 \mathrm{dBA}$, followed by funeral ground 3 of 83.6dBA, then funeral ground 2 of $79.2 \mathrm{dBA}$. The sampled churches and funeral gatherings, thus, exceeded their day time permissible EPA noise levels of $60 \mathrm{dBA}$ and $65 \mathrm{dBA}$ respectively. It is recommended that the public be made aware of the adverse effects of noise pollution and steps taken to enforce the EPA standards to protect inhabitants.
\end{abstract}

Keywords: Environmental Protection Agency, noise pollution, measurement, funeral, permissible noise levels, church.

Date of Submission: 13-07-2017

Date of acceptance: 15-07-2017

\section{INTRODUCTION}

Noise is a type of pollutant that is increasing very quickly as a result of growth in commercial, industrial and social activities in Ghana. It is known by many as unwanted sound which results from the activities of humankind [1]. Theresearch on sound covers all fields of sound production, propagation and reception; and is measured as sound pressure[2]. Sound is the result of pressure changes in a medium (usually air), caused by vibration or turbulence. The amplitude of these changes is stated in terms of sound level, and the rapidity with which these changes occur is the sound's frequency. Sound level is measured in decibels $(\mathrm{dB})$, and sound frequency is stated in terms of cycles per second, or hertz (Hz.). Sound level is logarithmic rather than a linear measure of the change in pressure with respect to a reference pressure level [3].

The effects of noise are determined mainly by duration and level of noise, but they are also influenced by the frequency. Long-lasting, high level sounds are the most damaging to hearing and generally the most annoying. High frequency sounds tend to be more hazardous to hearing and more annoying than low frequency sounds. Low frequency sounds appear to be somewhat less damaging to hearing than continuous sounds because of the ear's ability to regenerate during the intervening quiet periods. However, intermittent and impulsive sounds tend to be more annoying because of their unpredictability [3]. Two weighting networks, namely, $\mathrm{A}$ and $\mathrm{C}$ networks are used in the measurement of sound. However, for environmental purposes, the measurement is made using an Aweighted scale (dBA) because this scale measures sound level in approximately the same way as the human ear perceives it[2]. The Environmental Protection Agency (EPA) is the leading public body for protecting and improving the environment in Ghana. One essential mandate of EPA, Ghana, is to ensure that notices are issued in the form of directives, procedures or warning, as it may determine, for the purpose of controlling the volume, intensity, and quality of noise in the environment [4].

Noise pollution brings with it a lot of health concerns. The liturgies of Christianity in Ghana, especially in Kumasi are becoming "noisy" and some Churches do this under the assertion that they are expected to make a joyful noise to the Lord [5].Armah et al., [6], carried out a study to investigate the ambient noise levels fromreligious activities in residential neighbourhoods in the Cape Coast metropolis, a coastal city in Ghana. The results showed that most of the locations' recorded noise levels were above the maximum permissible limits set by the Environmental Protection Agency (EPA) 
and that the levels of noise exposure generally correlated with levels of annoyance of residents.

The enforcement of noise level limits and laws have not been effective. For example Wireko, [7], expresses her surprise why it took the city authorities so long in taking action against those engaged in noise making in Accra, while reacting to an article by the Ghana News Agency (GNA) in the February 15, 2013 issue of the Daily Graphic, which reported the demolition of a church by the Accra Metropolitan Assembly (AMA) for making excessive noise.Wiseman,[8], also laments on the excessive noise from churches by citing a case in Durham, North Carolina, USA, where in an article dated January 13, 2013 on ABC13.com, nine families living in The Hills at Southpoint subdivision, filed a lawsuit against the New Hope Church for refusing to turn down the volume of the music after they talked to the church about it.

At social gatherings, especially at church services, young children are seriously affected by excessive noise.Young children are vulnerable to noise in their physical environment [9]. Studies suggest that noise has effect on the unborn child; it is possible that when pregnant women are exposed to high levels of aircraft noise above $62 \mathrm{~dB}(\mathrm{~A})$, small reductions in birthweight occur [10]. The noise level at some gatherings are similar to the aircraft noise. In addition to hearing loss in children, noise exposure is associated with negative birth outcomes including, reduced cognitive function, inability to concentrate, increased psychosocial activation, nervousness, feeling of helplessness, and increased blood pressure in children [9]. In their study, Cohen et al., [11], observed a general deficit in task performance on puzzle task and increase in distractibility. This finding also supports the general hypothesis that prolonged noise exposure affects cognitive processes.

High noise exposure during critical periods in gestation is a potential stressor that may result in increased risk of implantation failure, dysregulation of placentation or decrease of uterine blood flow [12]. There is evidence from animal studies for associations between noise exposure and adverse reproductive outcomes; even though few studies have been conducted in humans, there is some suggestive evidence of adverse associations with environmental noise from both occupational and epidemiological studies, especially for low birthweight[12].

Apart from hearing damage and community annoyance, excessive noise pollution has also been blamed for hypertension, fatigue, heart trouble, disturbed serum lipid, triglycerides, platelet count, plasma viscosity, glucose and reduced motor efficiency [13]. Noise can influence the cardiovascular, endocrine, metabolic, gastrointestinal and neurological systems of humans [14]. The use of appropriate preventive measures can be used to mitigate the harmful effects of noise, which could be moderated and or even eliminated [15].

According to the World Health Organization (WHO), chronic exposure to noise can compromise health, and at least $30 \%$ of European citizens are exposed to night-time sound pressure levels that can seriously affect sleep [16], [17]. Generally, the major source of environmental noise is from road traffic, [18]. Next to road traffic are aircraft and rail noise [16]. Using disability-adjusted life years (DALYs) to quantify the effect of noise in Europe, the WHO estimates that 587,000 DALYs are lost per year due to noise within European cities, with road traffic noise contributing the major part [19]. EPA, Ghana, the government wing responsible for the prudent management of the environment, has set out guidelines that come with permissible ambient noise for the aforementioned areas. The environmental agency puts permissible ambient noise levels in residential areas at 55 decibels $(\mathrm{dB})$ during the day and $48 \mathrm{~dB}$ at night. Permissible noise levels around educational and health facilities has been put at $55 \mathrm{~dB}$ during the day and $50 \mathrm{~dB}$ at night, while the noise level for areas with commercial or light industrial activities is registered as $60 \mathrm{~dB}$ and $55 \mathrm{~dB}$ during the day and night respectively. The guidelines also permit $65 \mathrm{~dB}$ noise levels during the day and $60 \mathrm{~dB}$ during the night for light industrial areas and places of entertainment and public assembly such as churches and mosques. Predominantly commercial areas, according to the guidelines, are allowed $70 \mathrm{~dB}$ during the day and 65 $\mathrm{dB}$ at night, while the noise level for heavy industrial areas is pegged at $70 \mathrm{~dB}$ during the day and night. [20].

It has been observed that noise pollution in Kumasi,the capital city of the Ashanti Region and the second biggest city in Ghana, with approximately 2.0 million inhabitants, is on the ascendancy. It is situated about $250 \mathrm{~km}$ northwest of Accra and has a geographical location of $06^{\circ} 41^{\prime} \mathrm{N}$ latitude and $01^{\circ} 28^{\prime}$ Wlongitude.

The main objective of this study is to investigate noise levels in Kumasi by measuring noise levels at some identified areas in it to determine whether the noise generated during some social gathering, is beyond acceptable limits set by the EPA, Ghana, and make appropriate recommendations.

\section{MATERIALS AND METHODS}

The measurement of noise level was done using a sound level meter which conforms to IEC 61672 standards. The Instrumentation for the measurement of noise levels in this study was a 
In this research, DT-8852 precision digital sound level meter which conforms to IEC 61672 standards was used. To be precise, it was manufactured to IEC 61672-1 Type 2,ANSI S1.4 Type2standard, with $1 / 2$ inch dielectric condenser microphone and 1/3-octave filter with a frequency range and measuring range of $31.5 \mathrm{~Hz}-8 \mathrm{kHz}$ and $30 \mathrm{~dB}-130 \mathrm{~dB}$.

The instrument was calibrated before taking measurements. In the calibration procedure, the frequency weighting, time weighting and level range were switched to A-weighting, Fast, and 50$100 \mathrm{~dB}$ respectively. The microphone housing was inserted carefully into the $1 / 2$ inch insertion hole of the calibrator and the switch of the calibrator turned on. The call potentiometer of the unit was adjusted to display $94.0 \mathrm{~dB}$. This instrument was designed for noise project, quality control, illness prevention \& cure and all kinds of environmental sounds measurements.

Noise levels measured at the churches were done on three Sundays for a period of one hour each. For Church A, it was carried out from 7:51-8:51 am, Church B, 10:00-11:00 am and Church C, 7:30-8:30 am.On a zero gradient ground, the sound level meter was placed outside on tripod at 1.5 metre height and 3 metre distance from the sound source in the church auditorium.

Similarly, noise levels were measured at three funeral events for a period of 1 hour each. The noise measurement results were recorded by placing the sound level meter on a zero gradient ground on a tripod at 1.5 metre height and 3 metre distance from the sound source, loud speakers, without any obstacle in the way. The funeral grounds were Ayeduase School Park, Ayigya Park and Kotei School Park. The sound level meter software, MATLAB $^{\mathrm{TM}}$ and Microsoft Excel were used to analyse the recorded data.

\section{RESULTS AND DISCUSSIONS}

Measurements were recorded for a period of 1 hour at intervals of 1 second for every sampling location. Measured noise level was used in the calculation of the day time noise level for the locations. Equation 3was used in calculating the day time noise levels at the church services and Equation 4the day time noise levels for the funerals.Equations 3 and 4 are modifications of Equation 1. The church services were held in the mornings while the funerals were in the afternoons.

$L_{D}=10 \log \left[\frac{1}{2}\left[\left(10^{L_{A e q M} / 10}\right)+\left(10^{L_{\text {AeqA }} / 10}\right)\right]\right]$

$L_{N}=10 \log \left[\frac{1}{2}\left[\left(10^{L_{A e q E} / 10}\right)+\left(10^{L_{A e q N} / 10}\right)\right]\right]$
$L_{D}=10 \log \left[\left(10^{L_{\text {AeqM }} / 10}\right)\right]$
$L_{D}=10 \log \left[\left(10^{L_{A e q A} / 10}\right)\right]$

Where

$L_{\text {Aeq }}=$ The A-weighted equivalent sound pressure level

$L_{\text {Aeq } M}=$ The equivalent sound pressure for the morning measurement

$L_{\text {AeqA }}=$ The equivalent sound pressure level for the afternoon measurement

$L_{\text {AeqE }}=$ The equivalent sound pressure level for the evening measurement

$L_{\text {AeqN }}=$ The equivalent sound pressure level for the night measurement

$L_{D}=$ Day time noise level

$L_{N}=$ Night time noise level

[21]

Tables 1, 2 and 3 show sample raw data that was measured, recorded and used to compute for the equivalent sound levels in Church A, Church B and Church $\mathrm{C}$ respectively. The data was recorded every second for a period of one hour and the average reading calculated. The average value was used in Equation 3 to calculate the noise levels.

Table 1: Sample data for Church A

\begin{tabular}{lll}
\hline & Church A & (dBA) \\
\hline $7: 51: 01,70.50$ & $7: 51: 13,76.00$ & $7: 51: 25,75.30$ \\
$7: 51: 02,73.40$ & $7: 51: 14,72.50$ & $7: 51: 26,72.00$ \\
$7: 51: 03,78.20$ & $7: 51: 15,78.60$ & $7: 51: 27,73.70$ \\
$7: 51: 04,80.60$ & $7: 51: 16,75.30$ & $7: 51: 28,79.50$ \\
$7: 51: 05,74.90$ & $7: 51: 17,72.60$ & $7: 51: 29,81.50$ \\
$7: 51: 06,82.70$ & $7: 51: 18,76.50$ & $7: 51: 30,80.80$ \\
$7: 51: 07,82.50$ & $7: 51: 19,72.90$ & $7: 51: 31,83.30$ \\
$7: 51: 08,80.20$ & $7: 51: 20,75.30$ & $7: 51: 32,79.80$ \\
$7: 51: 09,79.60$ & $7: 51: 21,71.50$ & $7: 51: 33,78.60$ \\
$7: 51: 10,76.50$ & $7: 51: 22,75.30$ & $7: 51: 34,79.20$ \\
$7: 51: 11,77.80$ & $7: 51: 23,70.20$ & $7: 51: 35,81.60$ \\
$7: 51: 12,74.60$ & $7: 51: 24,77.70$ & $7: 51: 36,78.60$ \\
\hline
\end{tabular}

Table 2: Sample data for Church B

\begin{tabular}{lll}
\hline & Church B & (dBA) \\
\hline $10: 00: 01,82.10$ & $10: 00: 13,87.00$ & $10: 00: 25,83.10$ \\
$10: 00: 02,87.40$ & $10: 00: 14,84.30$ & $10: 00: 26,87.00$ \\
$10: 00: 03,84.70$ & $10: 00: 15,90.80$ & $10: 00: 27,88.10$ \\
$10: 00: 04,87.00$ & $10: 00: 16,90.40$ & $10: 00: 28,87.40$ \\
$10: 00: 05,83.30$ & $10: 00: 17,88.80$ & $10: 00: 29,90.00$ \\
$10: 00: 06,81.60$ & $10: 00: 18,86.60$ & $10: 00: 30,86.80$ \\
$10: 00: 07,88.80$ & $10: 00: 19,85.70$ & $10: 00: 31,88.40$ \\
$10: 00: 08,85.30$ & $10: 00: 20,87.40$ & $10: 00: 32,87.80$ \\
$10: 00: 09,87.30$ & $10: 00: 21,84.70$ & $10: 00: 33,86.80$ \\
$10: 00: 10,94.10$ & $10: 00: 22,85.10$ & $10: 00: 34,85.10$ \\
\hline
\end{tabular}



ISSN : 2248-9622, Vol. 7, Issue 7, ( Part -5) July 2017, pp.20-27

\begin{tabular}{lll}
\hline $10: 00: 11,96.80$ & $10: 00: 23,85.30$ & $10: 00: 35,87.40$ \\
$10: 00: 12,85.50$ & $10: 00: 24,87.20$ & $10: 00: 36,83.10$ \\
\hline
\end{tabular}

Table 3: Sample data for Church C

\begin{tabular}{lll}
\hline & Church C & (dBA) \\
\hline $7: 30: 01,87.40$ & $7: 30: 13,85.30$ & $7: 30: 25,81.20$ \\
$7: 30: 02,83.40$ & $7: 30: 14,76.90$ & $7: 30: 26,84.30$ \\
$7: 30: 03,96.80$ & $7: 30: 15,90.30$ & $7: 30: 27,83.40$ \\
$7: 30: 04,85.90$ & $7: 30: 16,97.80$ & $7: 30: 28,84.20$ \\
$7: 30: 05,77.00$ & $7: 30: 17,85.90$ & $7: 30: 29,82.50$ \\
\hline
\end{tabular}

\begin{tabular}{lll}
\hline $7: 30: 06,82.70$ & $7: 30: 18,81.00$ & $7: 30: 30,78.60$ \\
$7: 30: 07,84.60$ & $7: 30: 19,79.30$ & $7: 30: 31,89.80$ \\
$7: 30: 08,84.30$ & $7: 30: 20,81.60$ & $7: 30: 32,91.10$ \\
$7: 30: 09,83.10$ & $7: 30: 21,91.20$ & $7: 30: 33,84.30$ \\
$7: 30: 10,85.50$ & $7: 30: 22,78.60$ & $7: 30: 34,75.20$ \\
$7: 30: 11,81.20$ & $7: 30: 23,87.80$ & $7: 30: 35,79.20$ \\
$7: 30: 12,79.20$ & $7: 30: 24,82.50$ & $7: 30: 36,86.10$ \\
\hline
\end{tabular}

Figs. 1, 2 and 3 show the graphs of the sound levels measured during a period of one hour each for the churches

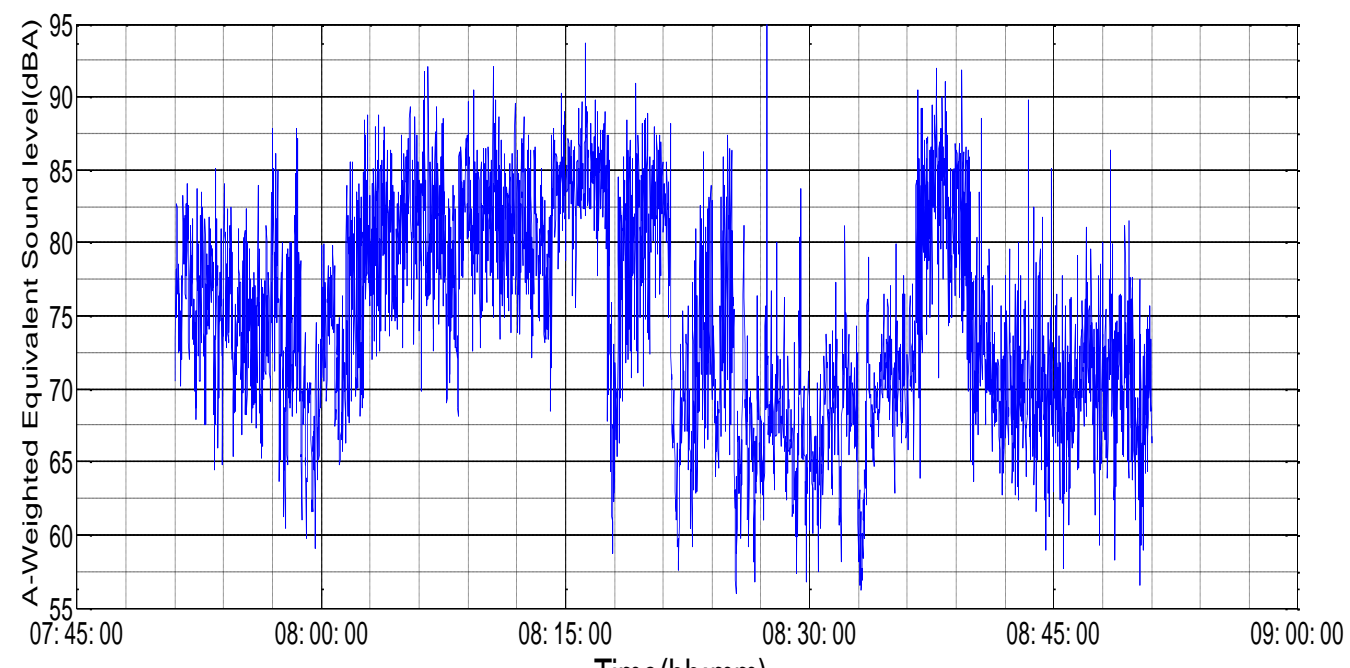

Time(hh:mm)

Figure 1: Graph of measured sound levels at Church A (Day 1)

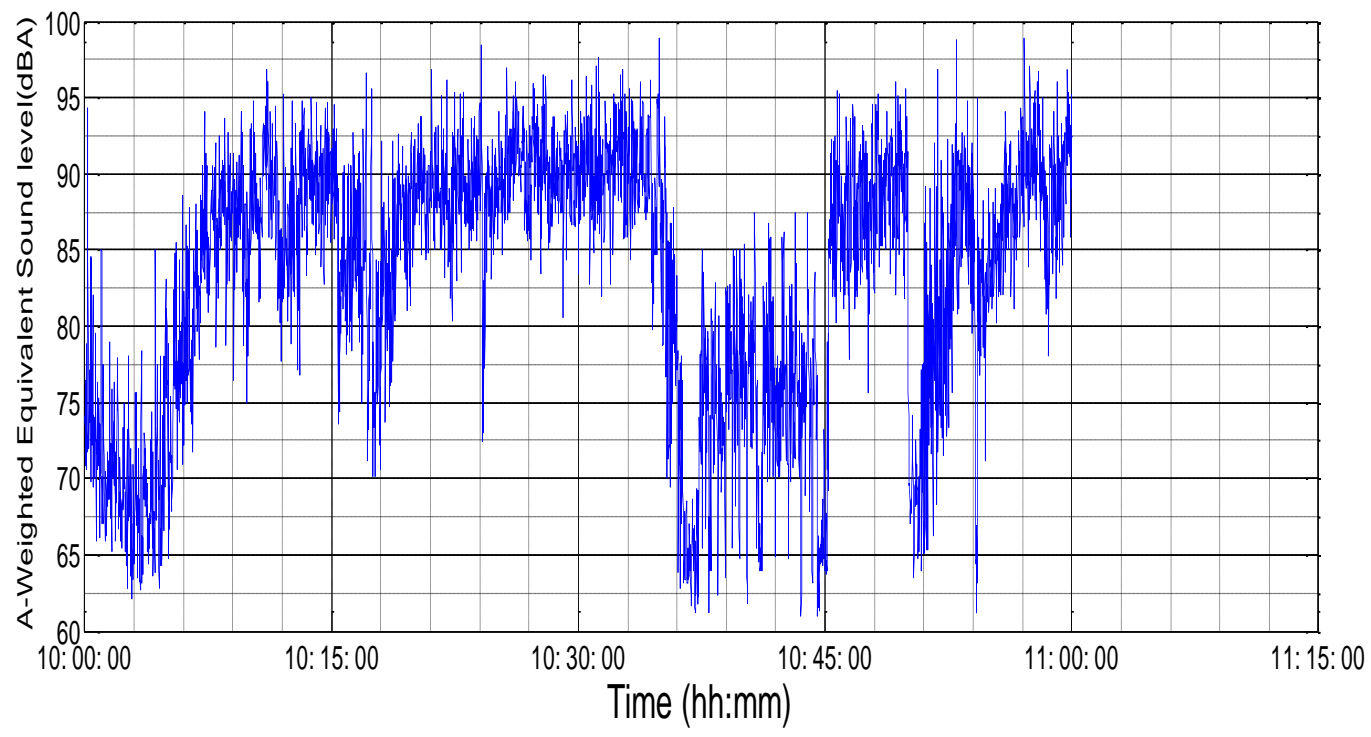

Figure 2: Graph of measured sound levels at Church B (Day 1) 


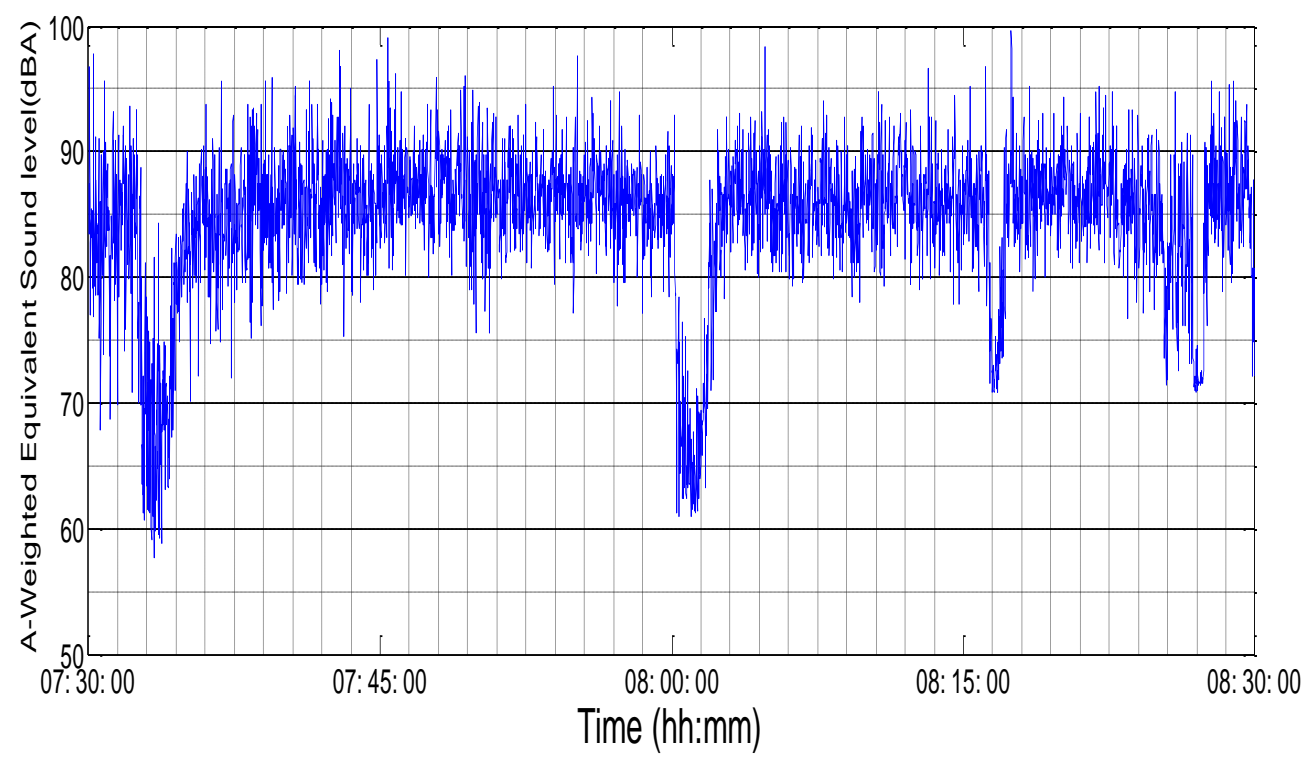

Figure 3: Graph of measured sound levels at Church C (Day 1)

The noise levels were calculated using Equation 3 and the results recorded. Table 4 shows the calculated noise levels for three Sundays for each church and the average noise level. Church A, Church B and Church $\mathrm{C}$ recorded $78.3 \mathrm{dBA}, 82.8$ $\mathrm{dBA}$ and $81.4 \mathrm{dBA}$ respectively as average noise levels for the three days.

Table 4: Equivalent Sound Levels at the Churches

\begin{tabular}{llll}
\hline & Church A & Church B & Church C \\
\hline Day 1 & $74.8 \mathrm{dBA}$ & $84.5 \mathrm{dBA}$ & $84.7 \mathrm{dBA}$ \\
& & & \\
Day 2 & $81.8 \mathrm{dBA}$ & $80.6 \mathrm{dBA}$ & $78.4 \mathrm{dBA}$ \\
& & & \\
Day 3 & $78.4 \mathrm{dBA}$ & $83.4 \mathrm{dBA}$ & $81 \mathrm{dBA}$ \\
Average: & $78.3 \mathrm{dBA}$ & $82.8 \mathrm{dBA}$ & $81.4 \mathrm{dBA}$ \\
\hline
\end{tabular}

The source of noise was mainly from loud speakers. The noise from all the speakers was mainly from musical instruments, praises, worship and preaching using microphones. Church B recorded the highest noise level as a result of noise from a number of loud speakers from intense praise and worship compared to Church $\mathrm{C}$ and Church B. The noise levels from the three Churches exceeded the maximum allowable limit of $60 \mathrm{dBA}$, during the day, set for light industrial areas and places of entertainment and public assembly such as churches and mosques as recorded in Table 5.

From Table 5, Churches A, B and C exceeded the allowable limit set by EPA by 18.3 $\mathrm{dBA}, 22.8 \mathrm{dBA}$ and $21.4 \mathrm{dBA}$ respectively.
Table 5: Excess dB from the three Churches

\begin{tabular}{lccc}
\hline & Church A & Church B & Church C \\
\hline $\begin{array}{l}\text { Noise } \\
\text { Level }\end{array}$ & $78.3 \mathrm{dBA}$ & $82.8 \mathrm{dBA}$ & $81.4 \mathrm{dBA}$ \\
$\begin{array}{l}\text { EPA noise } \\
\text { level limit }\end{array}$ & $60 \mathrm{dBA}$ & $60 \mathrm{dBA}$ & $60 \mathrm{dBA}$ \\
\begin{tabular}{l} 
Excess \\
\hline
\end{tabular} & $18.3 \mathrm{dBA}$ & $22.8 \mathrm{dBA}$ & $21.4 \mathrm{dBA}$ \\
\hline
\end{tabular}

Tables 6, 7 and 8 show sample raw data that was measured, recordedand used to compute for the equivalent sound levels in Funeral grounds 1,2 and 3 respectively.

Table 6: Sample data for Funeral ground 1

\begin{tabular}{lll}
\hline & \multicolumn{3}{l}{ Funeral ground } \\
& 1 & \\
\hline $13: 36: 01,85.60$ & $13: 36: 13,85.30$ & $13: 36: 25,83.30$ \\
$13: 36: 02,86.60$ & $13: 36: 14,86.30$ & $13: 36: 26,85.90$ \\
$13: 36: 03,87.40$ & $13: 36: 15,85.70$ & $13: 36: 27,84.50$ \\
$13: 36: 04,83.20$ & $13: 36: 16,83.40$ & $13: 36: 28,88.40$ \\
$13: 36: 05,86.30$ & $13: 36: 17,80.70$ & $13: 36: 29,90.10$ \\
$13: 36: 06,86.20$ & $13: 36: 18,86.20$ & $13: 36: 30,87.80$ \\
$13: 36: 07,85.10$ & $13: 36: 19,86.10$ & $13: 36: 31,88.80$ \\
$13: 36: 08,82.30$ & $13: 36: 20,85.60$ & $13: 36: 32,89.50$ \\
$13: 36: 09,87.80$ & $13: 36: 21,87.00$ & $13: 36: 33,88.40$ \\
$13: 36: 10,85.70$ & $13: 36: 22,84.90$ & $13: 36: 34,89.00$ \\
$13: 36: 11,84.90$ & $13: 36: 23,83.70$ & $13: 36: 35,93.60$ \\
$13: 36: 12,86.60$ & $13: 36: 24,85.50$ & $13: 36: 36,87.80$ \\
& & \\
\hline
\end{tabular}

Table 7: Sample data for Funeral ground 2

\begin{tabular}{lll}
\hline & $\begin{array}{l}\text { Funeral } \\
\text { ground 2 }\end{array}$ & \\
\hline $15: 07: 00,71.50$ & $15: 07: 12,80.80$ & $15: 07: 24,80.30$ \\
$15: 07: 01,86.60$ & $15: 07: 13,79.60$ & $15: 07: 25,74.90$ \\
$15: 07: 02,78.00$ & $15: 07: 14,75.30$ & $15: 07: 26,76.50$ \\
$15: 07: 03,76.10$ & $15: 07: 15,76.50$ & $15: 07: 27,78.60$ \\
\hline
\end{tabular}




\begin{tabular}{lll}
\hline $15: 07: 04,79.60$ & $15: 07: 16,78.40$ & $15: 07: 28,80.80$ \\
$15: 07: 05,78.00$ & $15: 07: 17,77.80$ & $15: 07: 29,79.10$ \\
$15: 07: 06,78.70$ & $15: 07: 18,76.10$ & $15: 07: 30,78.40$ \\
$15: 07: 07,76.30$ & $15: 07: 19,78.40$ & $15: 07: 31,79.20$ \\
$15: 07: 08,74.50$ & $15: 07: 20,78.80$ & $15: 07: 32,77.70$ \\
$15: 07: 09,75.50$ & $15: 07: 21,77.10$ & $15: 07: 33,76.50$ \\
$15: 07: 10,76.30$ & $15: 07: 22,80.30$ & $15: 07: 34,81.50$ \\
$15: 07: 11,77.70$ & $15: 07: 23,74.90$ & $15: 07: 35,78.70$ \\
\hline
\end{tabular}

Table 8: Sample data for Funeral ground 3

\begin{tabular}{lll}
\hline & $\begin{array}{l}\text { Funeral } \\
\text { ground 3 }\end{array}$ & \\
\hline $13: 14: 31,83.50$ & $13: 14: 42,86.50$ & $13: 14: 53,75.70$ \\
$13: 14: 32,88.60$ & $13: 14: 43,82.60$ & $13: 14: 54,78.80$ \\
$13: 14: 33,89.20$ & $13: 14: 44,85.30$ & $13: 14: 55,78.60$ \\
$13: 14: 34,83.50$ & $13: 14: 45,81.00$ & $13: 14: 56,81.00$ \\
$13: 14: 35,87.30$ & $13: 14: 46,86.60$ & $13: 14: 57,89.00$ \\
\hline
\end{tabular}

\begin{tabular}{lll}
\hline $13: 14: 36,87.80$ & $13: 14: 47,87.80$ & $13: 14: 58,88.50$ \\
$13: 14: 37,82.70$ & $13: 14: 48,84.60$ & $13: 14: 59,84.70$ \\
$13: 14: 38,87.40$ & $13: 14: 49,87.40$ & $13: 15: 00,83.70$ \\
$13: 14: 39,85.10$ & $13: 14: 50,82.30$ & $13: 15: 01,89.20$ \\
$13: 14: 40,84.10$ & $13: 14: 51,83.10$ & $13: 15: 02,87.00$ \\
$13: 14: 41,88.40$ & $13: 14: 52,83.30$ & $13: 15: 03,83.90$
\end{tabular}

Figs. 4, 5 and 6 show the graphs of the sound levels measured during a period of one hour at the various funeral grounds.

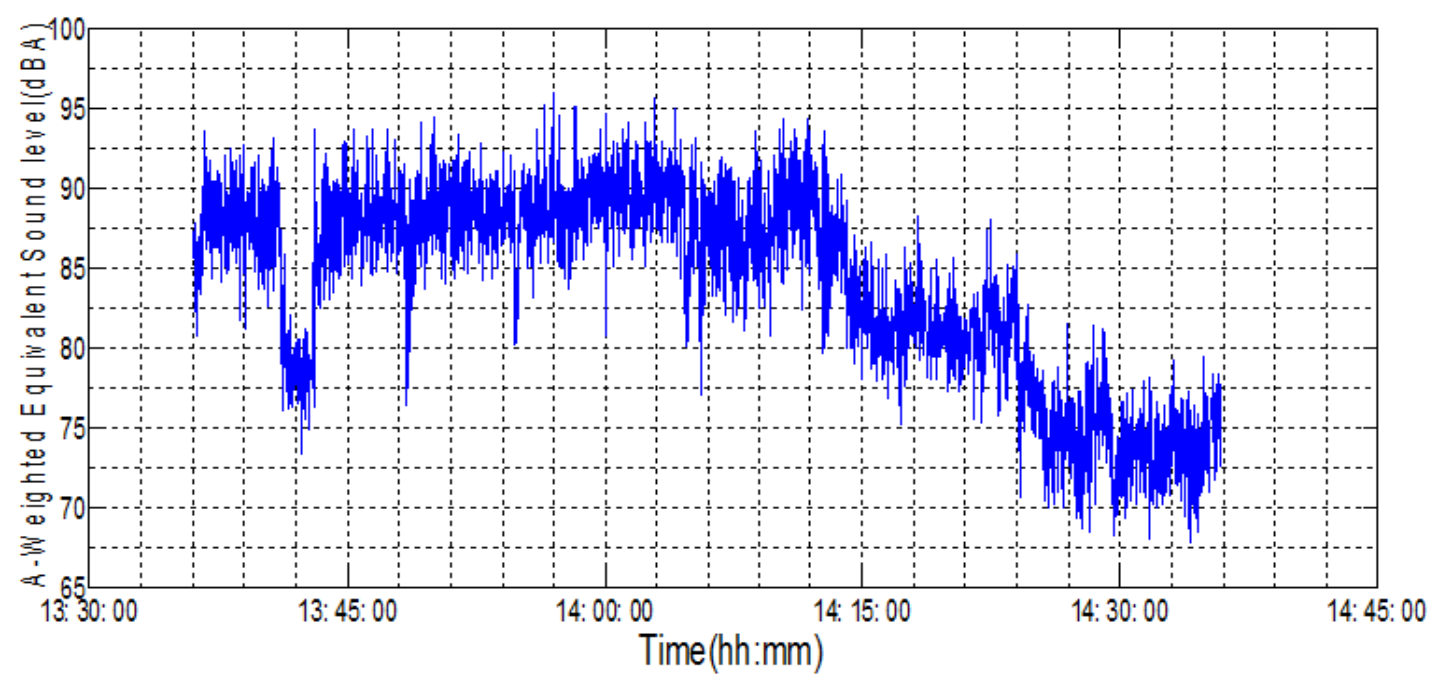

Figure 4: Graph of measured sound levels at Funeral ground 1

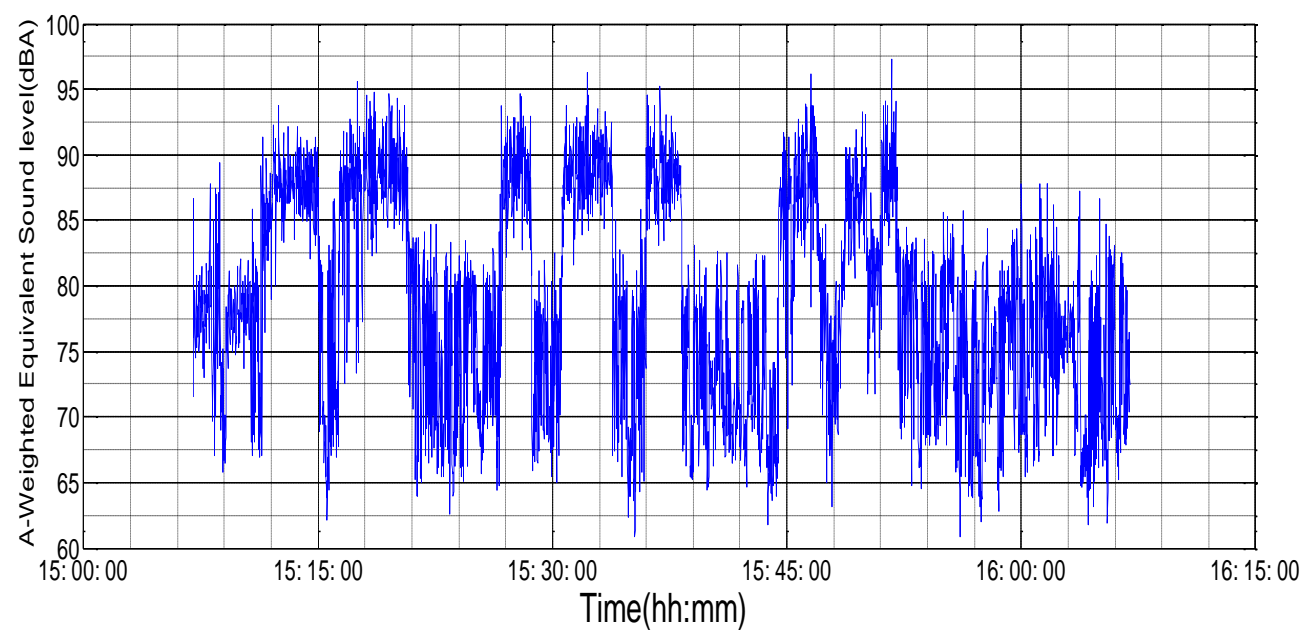

Figure 5: Graph of measured sound levels at Funeral ground 2 


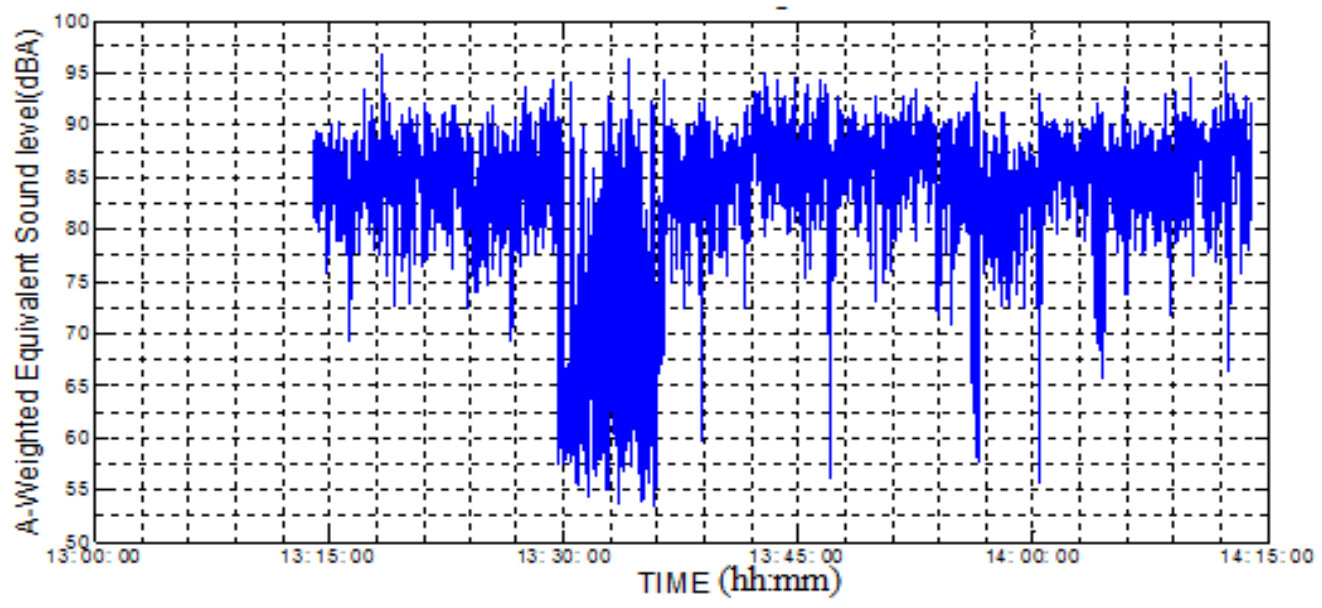

Figure 6: Graph of measured sound levels at Funeral ground 3

Table 9 shows that there are variations in noise levels at the funeral grounds. Funeral ground 1 recorded the highest noise level of $84 \mathrm{dBA}$, followed by funeral ground 3 of $83.6 \mathrm{dBA}$, then funeral ground 2 of $79.2 \mathrm{dBA}$.

Table 9: Equivalent Sound Levels at the Funeral Grounds

\begin{tabular}{lccc}
\hline & $\begin{array}{c}\text { Funeral } \\
\text { ground 1 }\end{array}$ & $\begin{array}{c}\text { Funeral } \\
\text { ground 2 }\end{array}$ & $\begin{array}{c}\text { Funeral } \\
\text { ground 3 }\end{array}$ \\
\hline $\begin{array}{l}\text { Noise Levels } \\
\text { EPA noise } \\
\text { level limit }\end{array}$ & $64 \mathrm{dbA}$ & $79.2 \mathrm{dBA}$ & $83.6 \mathrm{dBA}$ \\
Excess & $19 \mathrm{dBA}$ & $65 \mathrm{dBA}$ & $65 \mathrm{dBA}$ \\
\hline
\end{tabular}

Major sources of noise were from music played from DVD players. The noise emanated from large loudspeakers. Some funeral grounds had the volume of their music players very high. Funeral ground 1 had a number of larger loudspeakers compared to Funeral ground 2 and Funeral ground 3. This resulted in the recording of the highest noise level at Funeral ground 1 of $84 \mathrm{dBA}$.

The study showed that noise levels from the funeral ground exceeded the maximum allowable limit of $65 \mathrm{dBA}$ for public assembly by EPA Standards. Funeral ground 1 exceeded the allowable limit by $19 \mathrm{dBA}$, funeral ground 2 exceeded it by $14.2 \mathrm{dBA}$ and funeral ground 3 exceeded the allowable limit by $18.6 \mathrm{dBA}$.

\section{CONCLUSION}

To determine whether noise generated in Kumasi metropolis at social gathering is beyond acceptable limits by EPA standards, noise levels were measured. In Ghana, such social gatheringsincludechurch services and funerals. It was observed that the daytime noise levels from the Church A, Church B and Church $\mathrm{C}$ were $78.3 \mathrm{dBA}$, $82.8 \mathrm{dBA}$ and $81.4 \mathrm{dBA}$ respectively, which exceeded the maximum allowable limit of $60 \mathrm{dBA}$ during the day for light industrial areas and places of entertainment and public assembly, such as churches and mosques, by $18.3 \mathrm{dBA}, 22.8 \mathrm{dBA}$ and $21.4 \mathrm{dBA}$ respectively.

Funeral ground 1 recorded the highest noise level of $84 \mathrm{dBA}$, followed by funeral ground 3 of $83.6 \mathrm{dBA}$, then funeral ground 2 of $79.2 \mathrm{dBA}$. The study showed that noise levels from the funeral grounds exceeded the maximum allowable limit of 65 dBA for public assembly set by EPA by $19 \mathrm{dBA}$, $18.4 \mathrm{dBA}$ and 14.2 $\mathrm{dBA}$ respectively.

The noise levels experienced at the areas under study were unacceptable and could pose a health risk to the populace. This will affect their physical and mental well-being negatively. There is usually high presence of children at social gatherings. From the reviewed literature, environmental noise of the kind experienced in the study could be a serious public health issue. Thus the prolonged exposure to such noise levels, as experienced in this study, could have serious effect on the people, especially on children,the most venerable. There could be reduced weight of babies at birth, reduced cognitive function and increase in distractibility, inability to concentrate, increased psychosocial activation, nervousness, feeling of helplessness, and increased blood pressure; any of which could have serious bad health effect and therefore affect the development of such children.It is recommended that studies of cardiovascular effects and other ill health effects of noise on people, especially children, should be urgently stepped up since the effects in terms of length and quality of life is critical for children than for adults. 


\section{REFERENCES}

[1] Anomohanran, O. , Iwegbue, C. M. A., Oghenerhoro, O., Egbai,J. C. Investigation of environmental noise pollution level of Abraka in Delta State, Nigeria, Trends in Applied Sciences Research 3(4),2008, 292297.

[2] Alam, J. B., Alam, M. J. B., Rahman, M. M., Dikshit, A. K., Khan, S. K. Study on traffic noise level of Sylhet by multiple regression analysis associated with health hazards, Iranian Journal of Environmental Health Science \& Engineering, 3(2),2006, 71-78.

[3] Suter, A. Noise and Its Effects, Administrative Conference of the United States, November, 1991.

[4] Environmental Protection Agency (EPA), Ghana, Act 490, 1994.

[5] Kyei, S., \&Kuwornu-Adjaottor, J.E.T. Noisy or joyfully noisy: A study of Christian church services in Kumasi, American Journal of Arts and Humanities, 1, 2016, A25-A36. Retrieved from http://www.ASRAresearch.org/ajah-vol-1no-1-2016/

[6] Armah, F. A., Odoi, J. O., Yawson, D. O., Yengoh, G. T., Afrifa, E. K. A., \&Pappoe,A. N. M. Mapping of Noise Risk Zones Derived from Religious. Activities and Perceptions in Residential Neighbourhoods in the Cape CoastMetropolis, Ghana. Environmental Hazards, 9 (4),2010, 358368.

[7] Wireko, V.; (2013). Reality Zone: Clamp down on noise making - is it too little too late? (February 20, 2013 Daily Graphic), http://www.graphic.com.gh/features/features /reality-zone-clamp-down-on-noise-makingis-it-too-little-too-late.html; $\quad$ Accessed: February 15, 2017

[8] Wiseman, T. (2013); Church Noise Welcome to the Church of Noise. Acoustiblok Soundproofing; Source: http://info.acoustiblok.com/blog/bid/82584/ Church-Noise-Welcome-to-the-Church-ofNoise, (Accessed: February 15, 2017)

[9] Viet S. M, Dellarco M., Dearborn D. G. and Neitzel R. (2014). Assessment of Noise Exposure to Children: Considerations for the National Children's Study; Journal of Pregnancy and Child Health 2014, 1:1
[10] Passchier-Vermeer Willy and PasschierWim F. Noise Exposure and Public Health Prevention and Health, Leiden, Netherlands, Environmental Health Perspectives 1 (08), 2000, 1 23-131.

[11] Cohen S., Evans G. W., Krantz D. S., and Stokols D. Physiological, Motivational, and Cognitive effect of aircraft noise on Children: Moving from the Laboratory to the field.American Psycologist, 35 (3),1980, 231-243

[12] RistovskaG., $\quad$ LaszloH. E. and HansellA. L.Reproductive Outcomes Associated with Noise Exposure - A Systematic Review of the Literature, International Journal of Environmental Research and Public Health, 11(8), 2014, 7931-7952

[13] Regecova, V. and E. Kellerova. Effects of Urban noise pollution on blood pressure and heart rate in preschool children. Journal of Hypertension, 13,1995, 405-412.

[14] Anticaglia. J, and Cohen A. Extra-auditory effects of noise as a health hazard. American Industrial Hygiene Association journal, 31,1970,277-281.

[15] Jovanovic J.Effects of constant industrial noise on cardiovascular system of industrial workers, Doctoral thesis, University of Nis, 1990.

[16] Berglund, B, Lindvall, T, and Schwela, D. H. Guidelines for community noise. Geneva: World Health Organization, 1999.

[17] World Health Organization (WHO). Night noise guidelines for Europe. Copenhagen: WHO, 2009.

[18] Paunoviæ, K, Jakovljeviæ, B, and Belojeviæ, G. (2009). Predictors of noise annoyance in noisy and quiet urban streets. Science of the TotalEnvironment,407, 2009;407:3707-11.

[19] World Health Organization (WHO). Burden of disease from environmental noise. Bonn; 2011.

[20] Odoi-Larbi, S.EPA sets guidelines for noisemaking. The Chronicle, $16^{\text {th }}$ May, 2012, The Chronicle,

http://thechronicle.com.gh/?p=44464

[21] Olayinka O. S., Abdullahi S. A.A statistical analysis of the day-time and night-time noise levels in Ilorin Metropolis, Nigeria, Trends in Applied Sciences Research, 3(3), 2008, 253-266. 